\title{
授業への真剣さに着目した工学基礎物理の 授業評価の分析
}

Analysis of Student-Evaluation Data on the Teaching of Fundamental Physics in an Introductory Technology Course, Paying Attention to Students' Earnestness to Learn

\author{
西田昌 彦※1 \\ Masahiko NISHIDA
}

\begin{abstract}
How student evaluations of the teaching of fundamental physics for engineering relate to teaching strategy from academic 2004 to 2006 has been studied, focusing on students' earnestness to learn. The teaching emphasized instructing theoretical concepts for 2004 and solving problems for 2005. The instruction during 2006 offered a good balance between the strategy for 2004 and that for 2005. The first and second components produced by principal-component analysis of the evaluation data have indicated the quality of instruction and the scholastic ability of students, respectively, independent of the teaching strategy. While correlation between the second component and the degree of earnestness was positive for 2004 and negative for 2005, the correlation for 2006 has been negligible, as expected. Multiple-regression analysis between the evaluation data and students' exam scores has shown little correlation for 2006, in contrast to that for 2004, but similar to that for 2005. Finally, we can say that the teaching strategy for 2006 would lead to educational effects similar to those in 2005 when the exam scores were notably improved.

Keywords: Evaluation of Instruction, Fundamental Physics, Principal-Component Analysis, Students' Earnestness, Multiple-Regression Analysis, Exam Scores, Scholastic Ability of Students

キーワード : 授業評価, 工学基礎物理, 主成分分析, 学生の真剣さ, 重回帰分析, 試験の成績, 基礎 学力
\end{abstract}

\section{1.はじめに}

今日，多くの大学で実施されている「学生による授 業評価」では，授業を受けた学生がアンケートの設問 に段階式評価で回答するといった形式が取られてい る.この方法の長所は，設問が適切である限り，評価 データを効率的に回収・測定でき，しかも，授業を含 めて教育の質という数量化の難しい概念に対してその 評価を定量化できるという点にある。授業評価では, 設問に対して個々の学生がその状態（知的レベルや学 習意欲など）に基づいて主観的に判断し，その感想を 回答する，各々の設問は授業に対する学生の感想を測 定する一つの電極のようなものである。この意味で, 授業評価とは，電極を通して学生の発する応答信号の ようなものとして捉えることができる，ただし，測定 された信号は個々の学生の主観的判断に基づくデー夕 であることを忘れてはならない

平成 20 年 2 月 28 日受付

※ 1 金沢工業大学基礎教育部・数理工教育センター
理工系の大学における授業評価では, 学生の主観に 基づく授業評価データと試験の成績のような客観的測 定デー夕との相関についての分析が十分なされている とはいえない ${ }^{1)}$ ，2．ままた，授業評価と授業方法（授 業のやり方）との相関についての分析も十分にはなさ れていない2). 今日, 大学での授業に求められている のは，一つ一つの授業においてそれぞれの授業評価と その分析のデータを積み重ねることであろう.

筆者は金沢工業大学で平成16年度から18年度にかけ て工学基礎物理（波動, 熱学, 電気学) の授業（1 年 次生対象, 選択科目, 週 3 回, 10 週間, 平成16年度開 始）を担当し, 授業改善の試みとして年度ごとに授業 のやり方を変えてみた，その詳細については 3.2 節 で改めて述べるが, 平成16年度は自然法則や理論の解 説を中心とし, 平成17年度は演習問題の解法に重きを 置いた授業を実施した。それに伴って授業評価や成績 との相関がどのように変化するかを分析して報告し $た^{2)}$. 平成17年度での授業の教育的効果と問題点につ いては 3.1 節で述べるが, 平成18年度には更なる授 
業改善を目指して, 自然法則や理論の解説を中心とし ながらも演習問題の解法にも気を配り, 両方のバラン スを取る授業へとそのやり方を変えてみた，本論文で は，授業方法の違いによる授業評価の変化について， 特に, 学生が授業に取り組むときの真剣さに着目して 分析する。また，授業評価と試験の成績との相関を重 回帰分析によって調べ， 3 年間にわたる分析結果を比 較・検討する。

\section{2. 授業評価アンケート}

授業評価の設問については前論文で述べた $\left.か^{1)}, 2\right)$, 本節で簡単に触れておきたい。本研究の授 業評価アンケートの設問は平成16～18年度の授業で 共通であり，以下に示すように 9 項目に絞ってある. いずれも簡潔で，授業評価において定番の設問とみな せるものである。言うまでもなく，これら 9 項目から 派生する設問 ${ }^{3)}$ は無数あるが, 本研究では, 数多く の可能な設問を整理した上で，授業評価の設問を代表 するようにこれら 9 項目に絞ったのである。 また，設 問の数を必要最小限に抑えることはアンケートの必要 条件でもある。

第 1 項目から第 5 項目までは教員の，また，第 6 項 目から第 9 項目までは学生の授業への取り組みに対 する評価項目である．各設問に対する学生の満足度 を 5 段階で評価し，それを 5 点満点の得点と読み替え て分析する（1 全然そう思わない， 2 あまりそう思 わない， 3 どちらとも言えない，4 まあそう思う， 5 強くそう思う, の 5 段階). ただし, 授業レベルの 高さについの設問 (8) に対する満足度の方向が他の設 問とは逆になることに注意されたい，理解度を問う設 問 (7) とは別に設問 (8) を導入した理由は, 授業レべ ルは高いが内容はよく理解できたとか, 授業レベルは 高くないと思うがよく理解できなかったといった学生 の多様な見方に対処するためである ${ }^{1)}$ 。 また, 設問 (9) の配布資料とは理論や数式誘導に関する説明資料, 章 末の指定問題の解答例, 章末問題の類題からなるレ ポート課題などである ${ }^{1) ， 21 .}$

なお，本論文の主要目的である授業評価の年度間比 較を容易にするため, 波動, 熱学, 電気学の 3 分野で それぞれ測定・回収した 5 段階評価のデー夕を設問ご とに足し合わせた，本論文では，それを15点満点の得 点（3〜15点）とみなして分析する。また，前論文 と同様, 授業評価データ及び試験の得点を全て平均值 0 と分散 1 に標準化して分析する ${ }^{1)}{ }^{2}$.

[アンケート設問 $]$

（1）この授業での先生の話し方は明膫でしたか.

(2) この授業で黒板の文字や書き方は明瞭でしたか.

（3）この授業での先生の熱意を感じましたか.

（4）先生はシラバス通りに授業を進めていましたか.

（5）学生からの質問に対して先生は適切に答えていた
と思いますか.

（6）あなたはこの授業に真剣に取り組みましたか.

（7）あなたはこの授業の内容を理解できましたか.

（8）あなたはこの授業のレベルが高すぎると思います か.

（9）あなたはこの授業での配布資料が学習に役立った と思いますか.

\section{3. 工学基礎物理の授業方法}

\section{1 平成 17 年度の授業の教育的効果と問題点}

平成17年度では物理をほとんど初めて学ぶ立場の学 生のことを考慮して, 基礎的な演習問題の解法に重点 を置き, 演習問題を解く過程で関連する理論の解説に 時間を割くといった授業を実施した ${ }^{2)}$. 自然法則や理 論の解説を中心とする通常の授業を実施した平成16年 度と比べて, 試験の成績がかなり向上する結果となっ た. 特に,「基礎学力」の低い学生の成績向上が著しい. 同時に, 授業評価デー夕と試験の成績との相関がかな り小さくなることも分かった.

しかしながら，この成績向上に対しては，次のよう な理由で, 手放しで喜ぶわけにはいかない. 演習問題 の解法では計算に多くの時間を割かざるを得ず, 関連 する自然法則や理論の解説に割ける時間はどうしても 限られる。一方, われわれ教員が大学レベルの物理に おいて学生に最も学習してほしいことは, 自然法則や 原理から筋道を立てて個々の現象を説明するその論理 である，その理解を深めるために演習問題を解くので あるが，学生は演習問題に対する取り組みを単なる試 験のための準備と受け取り, 大学レベルでの物理の学 習を軽んじることになる恐れがある，また，その結果 として, 物理の問題を解くスキルは身に付ける（高校 物理の延長) が, その本質（自然法則や理論）はまる で分かっていないということになる恐れもある.

更に，文献 2 ）で報告・指摘したように，3 分野の うち特に波動と熱学の分野での授業評価デー夕の主成 分分析に抒いて，第 2 主成分に対する設問 (6)「授業 に対する学生の真剣さ」の係数が, 平成16年度では正 であるのに対して, 平成17年度では負になっている. 第 2 主成分とは，その具体的内容については 4.1 節 で改めて述べるが, 学生の「基礎学力」に対応した情 報を持つ要因である ${ }^{1) ， 2)}$ 。この第 2 主成分と設問 (6) との間の関係をもっと明確に示すために, 平成 16,17 年度での受講学生の第 2 主成分得点と設問 (6) との 相関関係を比較して図 1 に表示した。ただし，ここで 用いたデー夕は, 年度間比較を容易にするため, 前述 したように，3つの分野でそれぞれ収集したデータを 足し合わせて編集したものである. 図 1 から分かるよ うに，平成16，17年度の間に相関の顕著な違いが見ら

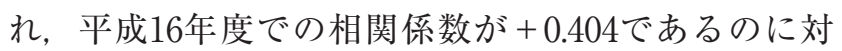

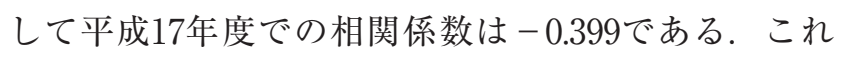




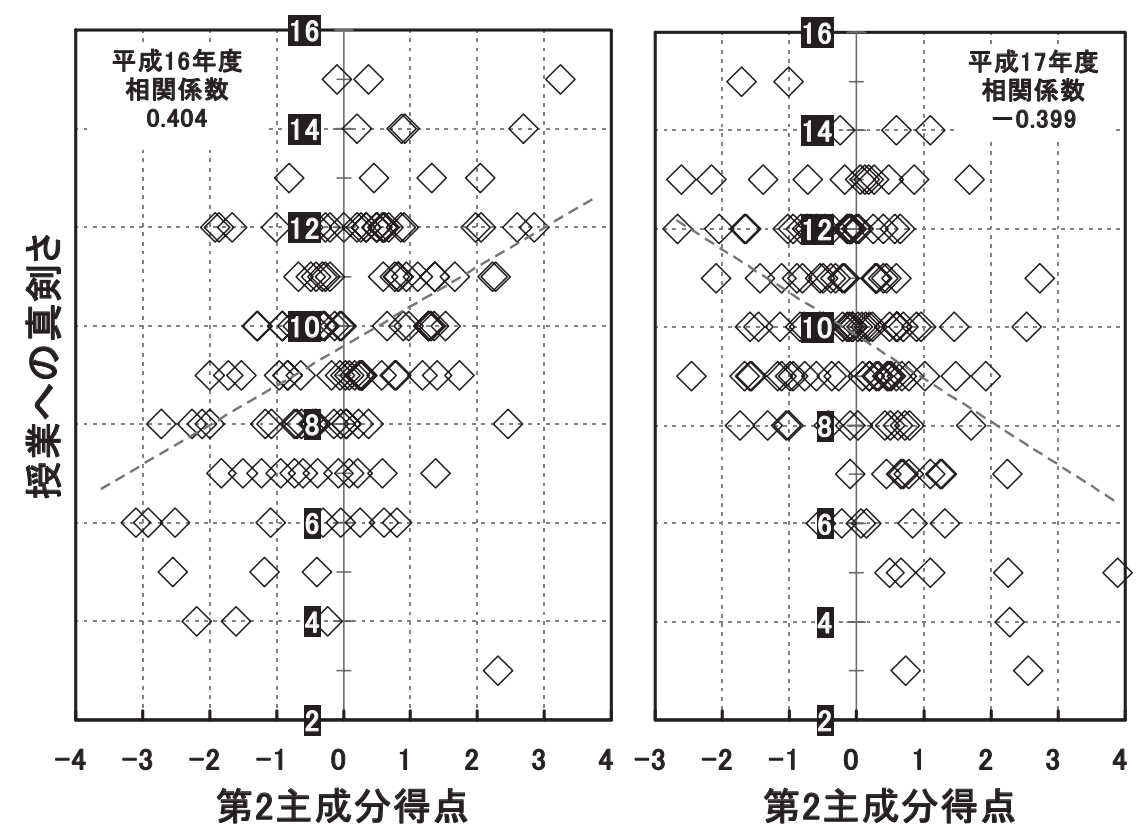

図 1 平成 16,17 年度 ·授業への真剣さ vs 第 2 主成分得点の関係

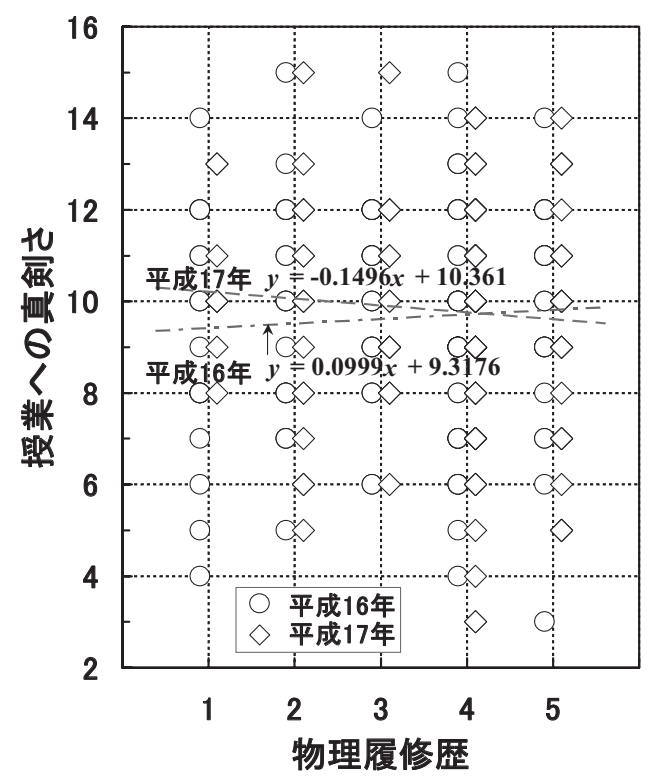

図 2 平成 16,17 年度・授業への真剣さ $\mathrm{vs}$ 高校での物理 履修歴の関係（1：履修せず，または，物理 IAのみ 履修， 2 : 物理 IB のみ履修，3:工業高校で履修，4： 非受験科目として物理 IB, II 履修, 5 ：受験科目とし て物理 IB, II 履修)

は，平成17年度の授業に対して基礎学力の高いほうの 学生の真剣さが減少し, またはその逆に, 基礎学力の 低いほうの学生の真剣さが増大したことを示唆してい る. 設問 (6) に対する学生の応答には, 授業への自ら の取り組み（出席状況, ノートの取り具合, レポート や試験への取り組みなど）に対するいろいろな思いが 含まれると考えられる。設問 (6) に対する応答は, 基 本的には, 学生の単位取得意欲の強さを反映するはず である ${ }^{1)}$.

一方, 平成 16,17 年度での受講学生の高校時代にお ける物理履修歴に対して設問 (6) をプロットしてみた
のが図 2 である。物理履修歴は受講学生の物理に関す る学力のおおよその目安になると考えられる. 物理履 修歴の調査のやり方と結果については文献 1), 2 ) を参照されたい. 分布傾向を分かりやすくするため, それぞれの年度の分布に対して最小二乗法による近 似回帰直線を破線で表示した。平成16年度では普通予 想されるように正の相関（回帰直線の傾きが正）を示 しているのに対して, 平成17年度では負の相関を示し ている。言い換えると, 平成 17 年度では高校時代に物 理をよく学習した学生のほうの真剣度が低く, 物理を あまり学習しなかった学生のほうの真剣度が高いとい う傾向が見られる。これは，図 1 に表示した第 2 主成 分得点と設問 (6) との間の相関関係と類似の傾向であ る. 平成17年度の授業の実施によって, 物理の基礎学 力の高いほうの学生は授業が易しいと感じ, 授業に真 剣に取り組む必要がなくなったことが原因と考えられ る. 或いはその逆に, 基礎学力の低いほうの学生が学 習しやすくなり, 授業に真剣に取り組むようになった ことが原因とも考えられる。 この傾向は明らかに平成 17年度での授業のやり方によって引き起こされたもの であり, 特に基礎学力の高いほうの学生の学習態度に 多少の行き過ぎが生じたことを示唆しているのではな いか. 言い換えると, 基礎学力の高い学生は授業のや り方を演習偏重, 理論軽視と受け取り, そのため授業 での学習態度において真剣さを低下させたのではない だろうか.

以上のような平成 17 年度の授業での問題点を改善す るため, 平成18年度では, 平成16年度と 17 年度のやり 方のバランスをとり, 自然法則や理論の解説を中心と しながらも演習問題の解法にも意を用いた授業へとそ のやり方を変えてみた，その意図するところは，第2 主成分得点「基礎学力」と「授業への真剣さ」との間 
の相関をできるだけ小さくすることにある.

\section{2 授業方法のまとめ}

授業のやり方で各年度に共通の事柄を簡潔にまとめ ておく.テキストとして「改訂版・基礎物理学」を用 い，黒板に板書しながら説明し，また，配布資料を OHPで表示して説明した。波動, 熱学, 及び, 電気 学の 3 分野の内容を講義し, 各部の最終授業において 授業評価のアンケート調査, レポートの提出, 及び, 学力試験 (40分程度の小テスト) を実施した (計 3 回). アンケートと成績との照合ができるように，また，学 生に評価の責任を持たせるために, 記名式で回答を求 めた．試験のでき具合で評価が左右されることがない ように, 試験実施前にアンケート調査を行った。更に, 学期末に全講義内容を範囲として期末試験(55分程度) を実施した．試験問題は各章末の演習問題の類題から なり,そのレベルは 3 年間にわたって同じ程度にして ある．履修学生の人数は平成 $16,17,18$ 年度でそれぞ れ184，167，152名（各年度で人数を 2 クラスに分け， それぞれに同じ授業を実施）であった（3 分野すべて のアンケートに回答した学生の人数は, これより若干 減る).

既に述べた部分もあるが，各年度での授業のやり方 のポイントをここにまとめておく.

(a) 平成16年度（期末試験受験者数145名）

1 ）通常の形式での授業.

2 ) 理論の解説（数式の誘導を含む）を中心とする.

3 ) 章末の演習問題 (10問程度指定) を各自で解き, その解法をレポートで提出させる.

(b) 平成 17 年度（期末試験受験者数 145 名）

1) 演習問題の解法に重点を置いた授業.

2 ) 演習問題（テキストの問い, 例題, 章末問題) を授業で解き, その過程で関連する理論の解説に も時間を割く。

3 ) 配布しておいた章末問題の類題 (レポート課題) を解かせて提出させる。

(c) 平成18年度（期末試験受験者数135名）

1) 理論の解説を中心としながらも演習問題の解法 にもかなり気を配る授業.

2 ）章末の演習問題の詳細な解答をつくり, 小テス トの10日ほど前に学生に配布する。

3 ）小テストの 1 回前の授業において, 配布した解 答の解説と関連する理論の復習をする.

4 ) 配布しておいた章末問題の類題 (レポート課題) を解かせて提出させる。

\section{4. 分析結果と考察}

\section{1 授業評価データの主成分分析}

3つの分野でそれぞれ回収したデー夕を足し合わせ て編集した授業評価データから設問間の相関係数を求 め, 相関行列（9次の対称行列）を作成して主成分分
析した，得られた 9 個の主成分（固有ベクトル）を年 度別に表 1 に示す。第 1 主成分に打いて項目 (8) の倸 数のみが負の值になっているのは, 項目 (8) が授業レ ベルの高さを問う設問だからである. いずれの年度で も, 授業評価データの持つ情報の $50 \%$ 以上が第 1,2 主成分に集約されており（累積寄与率が0.5以上），第 3 以上の主成分はいずれもその固有值が 1 程度以下な ので, その寄与は無視してよ( ${ }^{1)}$, 2). 以下に, 第 1, 2 主成分を視覚化してそれぞれの特徵を簡潔に述べる。

図 3 は第 1,2 主成分に対して設問項目の係数（重 み）をプロットしたものである，第 1 主成分に対する 各項目の重みには年度による多少の増減はあるが, そ の性格には年度による本質的な違いはなく, 第 1 主成 分は教員の取り組みに重みを置いた「授業の良さ（ま たは質)」の性格をもつと考えてよい1)，2．

これに対して，第 2 主成分と設問項目の関係につい ては，3．1節でその一部を述べたが，いずれの年度 でも第 2 主成分への教員の取り組みの寄与は小さく, 項目 (7)「授業理解度」と項目 (8)「授業レベルの高 さ」の係数の絶対值が大きいので, 第 2 主成分は基本 的に「学生の基礎学力」の性格をもつと解釈してよ ( $1{ }^{1)}$ ，2). ただし, 既に述べたように, 第 2 主成分に 対する項目 (6) の重みには年度による違いがあり, 項 目 (6) の係数が平成16年度では正であるのに対して, 平成17年度では負になっている。一方, 理論の解説と 演習問題の解法のバランスを取った平成18年度の授業 では, 図 3 に示すように, 第 2 主成分に対する項目 (6) の重みはほぼ0であり, 相対的に項目 (7) と項目（8） の重みがそれだけ増して, 第 2 主成分の「基礎学力」 としての性格がより強くなっている。平成16,17年度 に対する図 1 の関係と比較するため, 平成18年度での 第 2 主成分得点に対する「授業への真剣さ」の関係を 図 4 に示す。その傾きは平成17年度の授業と同様に依 然として負ではあるが, 相関係数の大きさは大幅に小 さくなっている（相関係数-0.167）。これは, 平成 18 年度の授業では, 学生の「授業への真剣さ」がその基 礎学力にほとんどよらなくなったことを意味し, 3.1 節で述べた当初の目的をほぼ達していることになる。

\section{2 授業評価データと成績との相関の分析}

試験の得点を目的変数 (被説明変数), 授業評価デー 夕の 9 個の主成分を説明変数として重回帰分析を実施 し, 授業評価データと試験の成績との間の相関を調べ た．年度間で比較するため, まず，期末試験の得点を 目的変数として重回帰分析を試みた。 その結果を表 2 に示す. 目的変数に対する説明変数の重み（標準偏回 帰係数）は, 主成分間に相関がないので, そのまま各 主成分と目的変数との間の相関係数を与えることに注 意されたい. 分散分析による検定によれば, 平成16年 度の重回帰分析は $1 \%$ 以下の水準で十分に有意である のに対して, 平成 17,18 年度の分析は $5 \%$ の水準です 
表 1 授業評価データの主成分分析表（固有ベクトル）

\begin{tabular}{|c|c|c|c|c|c|c|c|c|c|}
\hline \multicolumn{10}{|c|}{ 平成16年度 } \\
\hline 設問項目 & $\begin{array}{c}\text { 第1 } \\
\text { 主成分 }\end{array}$ & $\begin{array}{l}\text { 第2 } \\
\text { 主成分 }\end{array}$ & $\begin{array}{l}\text { 第3 } \\
\text { 主成分 }\end{array}$ & $\begin{array}{c}\text { 第4 } \\
\text { 主成分 }\end{array}$ & $\begin{array}{c}\text { 第5 } \\
\text { 主成分 }\end{array}$ & $\begin{array}{c}\text { 第6 } \\
\text { 主成分 }\end{array}$ & $\begin{array}{c}\text { 第7 } \\
\text { 主成分 }\end{array}$ & $\begin{array}{c}\text { 第8 } \\
\text { 主成分 }\end{array}$ & $\begin{array}{c}\text { 第9 } \\
\text { 主成分 }\end{array}$ \\
\hline (1) & 0.434 & -0.142 & -0.175 & 0.048 & -0.285 & -0.111 & -0.192 & 0.037 & $=0.792$ \\
\hline (2) & 0.406 & -0.113 & -0.171 & 0.301 & -0.327 & -0.367 & -0.339 & -0.234 & 0.539 \\
\hline (3) & 0.395 & -0.122 & 0.027 & -0.115 & -0.374 & 0.117 & 0.781 & 0.159 & 0.162 \\
\hline (4) & 0.309 & -0.309 & 0.214 & 0.626 & 0.565 & 0.112 & 0.105 & 0.168 & -0.021 \\
\hline (5) & 0.378 & -0.115 & 0.147 & -0.339 & 0.022 & 0.730 & -0.363 & -0.149 & 0.145 \\
\hline (6) & 0.197 & 0.329 & 0.765 & -0.052 & -0.001 & -0.257 & 0.068 & -0.424 & -0.123 \\
\hline (7) & 0.264 & 0.619 & 0.079 & 0.011 & -0.008 & -0.028 & -0.201 & 0.699 & 0.104 \\
\hline (8) & -0.156 & -0.589 & 0.468 & -0.258 & -0.169 & -0.252 & -0.217 & 0.446 & 0.070 \\
\hline (9) & 0.347 & -0.071 & -0.247 & -0.564 & 0.568 & -0.405 & 0.066 & -0.031 & 0.058 \\
\hline 固有值 & 3.975 & 1.509 & 1.026 & 0.581 & 0.573 & 0.487 & 0.410 & 0.245 & 0.192 \\
\hline 寄与率 & 0.442 & 0.168 & 0.114 & 0.065 & 0.064 & 0.054 & 0.046 & 0.027 & 0.021 \\
\hline 累積寄与率 & 0.442 & 0.609 & 0.723 & 0.788 & 0.852 & 0.906 & 0.951 & 0.979 & 1.000 \\
\hline \multicolumn{10}{|c|}{ 平成17年度 } \\
\hline 設問項目 & $\begin{array}{l}\text { 第1 } \\
\text { 主成分 }\end{array}$ & $\begin{array}{c}\text { 第2 } \\
\text { 主成分 }\end{array}$ & $\begin{array}{l}\text { 第3 } \\
\text { 主成分 }\end{array}$ & $\begin{array}{c}\text { 第4 } \\
\text { 主成分 }\end{array}$ & $\begin{array}{c}\text { 第5 } \\
\text { 主成分 }\end{array}$ & $\begin{array}{c}\text { 第6 } \\
\text { 主成分 }\end{array}$ & $\begin{array}{c}\text { 第7 } \\
\text { 主成分 }\end{array}$ & $\begin{array}{c}\text { 第8 } \\
\text { 主成分 }\end{array}$ & $\begin{array}{c}\text { 第9 } \\
\text { 主成分 }\end{array}$ \\
\hline$\overline{(1)}$ & 0.438 & $=0.122$ & -0.069 & $=0.277$ & $=0.221$ & $=0.233$ & $=0.146$ & $=0.291$ & $=0.709$ \\
\hline (2) & 0.398 & -0.137 & 0.022 & -0.554 & 0.019 & -0.247 & -0.198 & -0.091 & 0.638 \\
\hline (3) & 0.406 & -0.167 & -0.145 & 0.040 & -0.137 & 0.106 & 0.862 & 0.079 & 0.075 \\
\hline (4) & 0.243 & -0.067 & -0.582 & 0.581 & 0.026 & -0.432 & -0.215 & 0.082 & 0.136 \\
\hline (5) & 0.354 & 0.062 & -0.353 & -0.066 & 0.046 & 0.771 & -0.316 & 0.213 & -0.022 \\
\hline (6) & 0.245 & -0.364 & 0.507 & 0.485 & -0.304 & 0.229 & -0.184 & -0.329 & 0.167 \\
\hline (7) & 0.323 & 0.427 & 0.405 & 0.082 & -0.273 & -0.188 & -0.080 & 0.651 & -0.049 \\
\hline (8) & -0.199 & -0.777 & 0.004 & -0.123 & -0.065 & -0.048 & -0.096 & 0.559 & -0.116 \\
\hline (9) & 0.311 & -0.107 & 0.299 & 0.120 & 0.871 & -0.048 & 0.029 & 0.058 & -0.150 \\
\hline 周有值 & 3.656 & 1.202 & 1.067 & 0.836 & 0.681 & 0.573 & 0.429 & 0.341 & 0.215 \\
\hline 寄与率 & 0.406 & 0.134 & 0.119 & 0.093 & 0.076 & 0.064 & 0.048 & 0.038 & 0.024 \\
\hline 累積寄与率 & 0.406 & 0.540 & 0.658 & 0.751 & 0.827 & 0.890 & 0.938 & 0.976 & 1.000 \\
\hline \multicolumn{10}{|c|}{ 平成18年度 } \\
\hline 設問項目 & $\begin{array}{l}\text { 第1 } \\
\text { 主成分 }\end{array}$ & $\begin{array}{c}\text { 第2 } \\
\text { 主成分 }\end{array}$ & $\begin{array}{l}\text { 第3 } \\
\text { 主成分 }\end{array}$ & 主成分 & $\begin{array}{c}\text { 第5 } \\
\text { 主成分 }\end{array}$ & $\begin{array}{c}\text { 第6 } \\
\text { 主成分 }\end{array}$ & $\begin{array}{c}\text { 第7 } \\
\text { 主成分 }\end{array}$ & $\begin{array}{c}\text { 第8 } \\
\text { 主成分 }\end{array}$ & $\begin{array}{c}\text { 第9 } \\
\text { 主成分 }\end{array}$ \\
\hline (1) & 0.410 & $=0.025$ & $=0.357$ & $=0.277$ & $=0.117$ & $=0.179$ & $=0.061$ & -0.166 & $=0.742$ \\
\hline (2) & 0.408 & 0.035 & -0.282 & -0.390 & 0.040 & -0.149 & 0.288 & -0.374 & 0.595 \\
\hline (3) & 0.383 & -0.337 & -0.176 & -0.071 & -0.163 & -0.043 & -0.295 & 0.732 & 0.231 \\
\hline (4) & 0.311 & -0.294 & 0.005 & 0.743 & -0.348 & -0.149 & 0.284 & -0.202 & 0.015 \\
\hline (5) & 0.388 & -0.007 & 0.116 & 0.013 & 0.023 & 0.902 & -0.058 & -0.132 & -0.033 \\
\hline (6) & 0.233 & -0.135 & 0.821 & -0.295 & -0.249 & -0.229 & -0.170 & -0.150 & -0.009 \\
\hline$(7)$ & 0.267 & 0.564 & 0.216 & 0.009 & 0.017 & -0.040 & 0.588 & 0.449 & -0.121 \\
\hline (8) & -0.122 & -0.678 & 0.108 & -0.210 & 0.358 & 0.073 & 0.545 & 0.112 & -0.162 \\
\hline (9) & 0.362 & 0.048 & 0.127 & 0.288 & 0.803 & -0.221 & -0.266 & -0.046 & -0.012 \\
\hline 直有值 & 3.748 & 1.525 & 0.929 & 0.685 & 0.591 & 0.511 & 0.376 & 0.338 & 0.296 \\
\hline 寄与率 & 0.416 & 0.169 & 0.103 & 0.076 & 0.066 & 0.057 & 0.042 & 0.038 & 0.033 \\
\hline 累積寄与率 & 0.416 & 0.586 & 0.689 & 0.765 & 0.831 & 0.888 & 0.930 & 0.967 & 1.000 \\
\hline
\end{tabular}

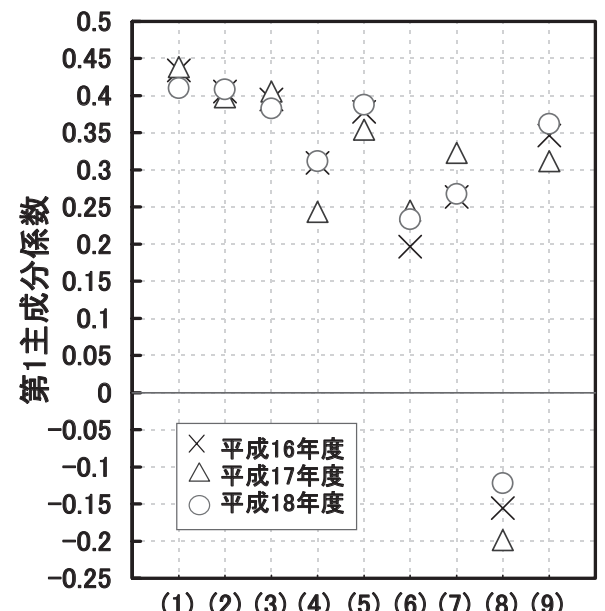

(1) (2) (3) (4) (5) (6) (7) (8) (9) 設問項目

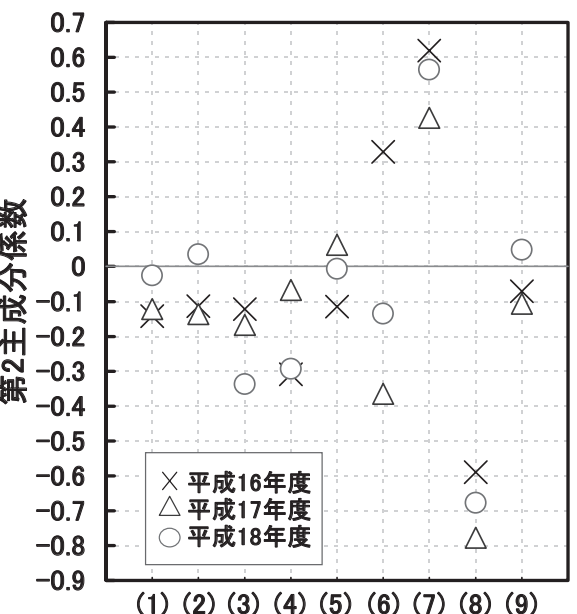

設問項目

図 3 第 1,2 主成分 vs 設問項目の関係 
ら有意でない. 特に, 平成 18 年度の授業では授業評価 と期末試験得点との間には相関は事実上無いと言って よい. 次に, 3 分野 (波動, 熱学, 電気学) の小テス トの合計得点に対しても同様の重回帰分析を試みた。

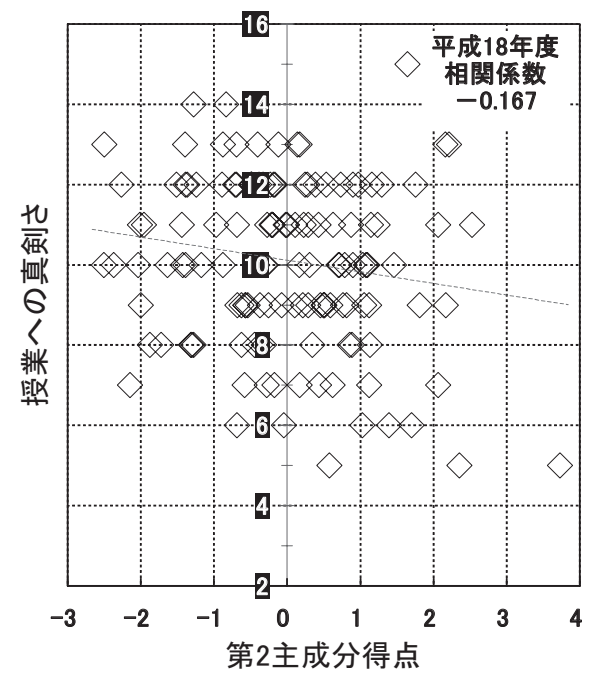

図 4 平成 18 年度・授業への真剣さ vs 第 2 主成分得点の関係
図 5 は, 学生の第 2 主成分得点「基礎学力」に対して, 3 分野の小テストの合計得点を年度別にプロットした ものである。平成16年度から18年度へと，「基礎学力」 に対する試験得点の相関度が減少していることが分か る.

最後に, 3 年間にわたる試験の成績と授業理解度と の関係を図 6 に示す。これは教員にとって最も関心の 高い関係の一つである。試験問題のレベルは 3 年間で 同じ程度にしてあるので，ここでは，平成16〜18年 度に受講した全学生の小テストの得点合計をまとめて 一体化し，その平均点と標準偏差に対して得点を標準 化した.したがって, 図 6 の得点は 3 年間統一の成績 を表している。また，得点分布の傾向を分かりやすく するため, それぞれの年度の得点分布に対して最小二 乗法による近似回帰直線を破線で表示してある。平成 16 年度に比べると, 平成 17,18 年度の回帰直線はほほ 同程度に平坦であり，授業理解度と試験得点との間の 相関度が低いことが見て取れる。平成17，18年度での 試験の得点レベルは全体的に高く，しかも，理解度の 低いほうの学生が高い得点を得る傾向が見られる。こ

表 2 主成分よる期末試験得点（目的変数）の重回帰分析表

\begin{tabular}{|c|c|c|c|c|c|c|c|c|c|}
\hline \multirow{3}{*}{ 主成分 } & \multicolumn{3}{|c|}{ 平成16年度 } & \multicolumn{3}{|c|}{ 平成17年度 } & \multicolumn{3}{|c|}{ 平成18年度 } \\
\hline & \multirow{2}{*}{$\begin{array}{l}\text { 標準偏 } \\
\text { 回帰係数 }\end{array}$} & \multicolumn{2}{|c|}{ 検定 } & \multirow{2}{*}{$\begin{array}{c}\text { 標準偏 } \\
\text { 回帰係数 }\end{array}$} & \multicolumn{2}{|c|}{ 検定 } & \multirow{2}{*}{$\begin{array}{c}\text { 標準偏 } \\
\text { 回帰係数 }\end{array}$} & \multicolumn{2}{|c|}{ 検定 } \\
\hline & & F 值 & $\mathrm{p}$ 值 & & F 值 & $\mathrm{p}$ 值 & & $\mathrm{F}$ 值 & $\mathrm{p}$ 值 \\
\hline 1 & 0.293 & 17.18 & $6.00 \mathrm{E}-05$ & $\begin{array}{l}-0.013 \\
\end{array}$ & 0.02 & $8.77 \mathrm{E}-01$ & 0.057 & 0.44 & $5.09 \mathrm{E}-01$ \\
\hline 2 & 0.424 & 36.03 & $1.71 \mathrm{E}-08$ & 0.206 & 6.44 & $1.23 \mathrm{E}-02$ & 0.149 & 2.96 & $8.78 \mathrm{E}-02$ \\
\hline 3 & 0.025 & 0.13 & $7.21 \mathrm{E}-01$ & 0.022 & 0.07 & $7.91 \mathrm{E}-01$ & 0.044 & 0.26 & $6.13 \mathrm{E}-01$ \\
\hline 4 & 0.132 & 3.51 & $6.31 \mathrm{E}-02$ & -0.007 & 0.01 & $9.35 \mathrm{E}-01$ & 0.060 & 0.47 & $4.92 \mathrm{E}-01$ \\
\hline 5 & 0.111 & 2.45 & $1.20 \mathrm{E}-01$ & -0.054 & 0.44 & $5.08 \mathrm{E}-01$ & -0.066 & 0.57 & $4.50 \mathrm{E}-01$ \\
\hline 6 & 0.105 & 2.22 & $1.39 E-01$ & -0.117 & 2.08 & $1.52 \mathrm{E}-01$ & -0.032 & 0.14 & $7.10 \mathrm{E}-01$ \\
\hline 7 & -0.064 & 0.83 & $3.65 E-01$ & -0.087 & 1.16 & $2.84 \mathrm{E}-01$ & -0.055 & 0.41 & $5.23 \mathrm{E}-01$ \\
\hline 8 & 0.135 & 3.65 & $5.83 E-02$ & -0.144 & 3.13 & $7.89 \mathrm{E}=02$ & 0.161 & 3.45 & $6.55 E-02$ \\
\hline 9 & -0.020 & 0.08 & $7.80 E-01$ & 0.136 & 2.78 & $9.77 E-02$ & 0.030 & 0.12 & $7.27 E-01$ \\
\hline \multirow[t]{3}{*}{ 定数項 } & 0 & & & 0 & & & 0 & & \\
\hline & \multicolumn{3}{|c|}{ 重相関係数: 0.575} & \multicolumn{3}{|c|}{ 重相関係数: 0.327} & \multicolumn{3}{|c|}{ 重相関係数: 0.257} \\
\hline & $\begin{array}{l}\text { 分散分析に } \\
\text { よる検定 }\end{array}$ & $\begin{array}{c}\mathrm{F} \text { 值 } \\
7.34\end{array}$ & $\begin{array}{c}\mathrm{p} \text { 值 } \\
1.18 \mathrm{E}-08\end{array}$ & $\begin{array}{l}\text { 分散分析に } \\
\text { よる検定 }\end{array}$ & $\begin{array}{c}\mathrm{F} \text { 值 } \\
1.79\end{array}$ & $\begin{array}{c}\mathrm{p} \text { 值 } \\
7.50 \mathrm{E}-02\end{array}$ & $\begin{array}{l}\text { 分散分析に } \\
\text { よる検定 }\end{array}$ & $\begin{array}{c}\mathrm{F} \text { 值 } \\
0.98\end{array}$ & $\begin{array}{c}p \text { 值 } \\
4.59 \mathrm{E}-01\end{array}$ \\
\hline
\end{tabular}
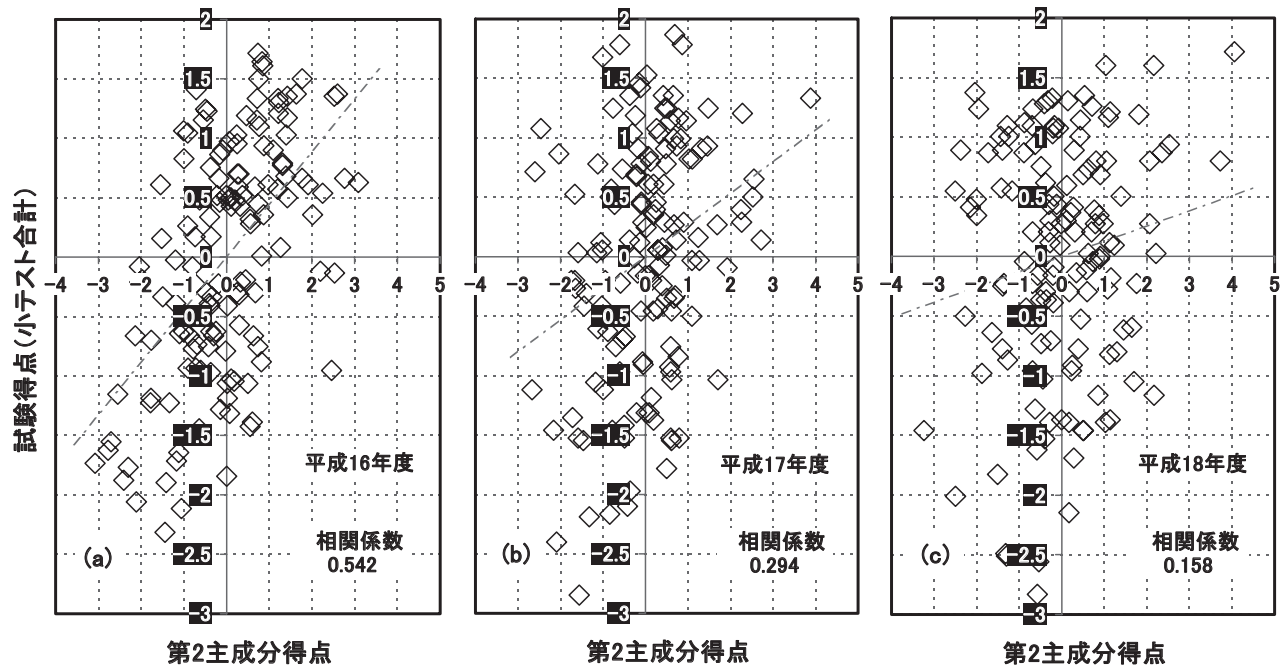

図 5 試験得点（小テスト得点合計の標準化得点）vs 第 2 主成分得点の関係 


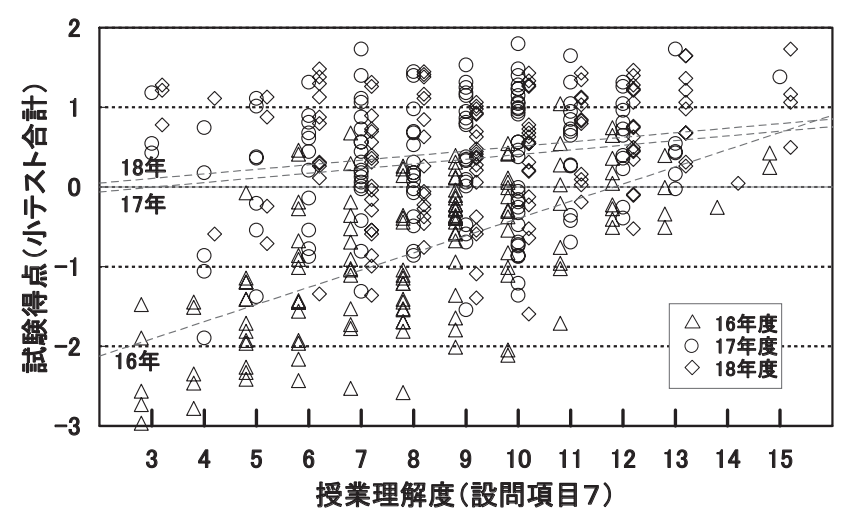

図 6 試験得点（小テスト得点合計の標準化得点）vs 授業 理解度の関係

れは授業が分からなくても試験において得点できる という意味では必ずしもない，むしろ，授業が分か るか分からないかは個々の学生の状態に基づく主観 であり，感想であるという点を反映していると考え るべきであろう ${ }^{4}$.

総じて, 平成 17,18 年度の授業評価デー夕と試験 の成績との間の相関度は平成16年度に比べてはるか に小さく, 授業評価データから学生の試験の成績を 予測することは困難である。平成16年度の授業と平 成17，18年度の授業との間の特徵的な違いは，後者 において演習問題の解法を重視したという点にある. また，平成18年度での試験の得点レベルとその傾向 的特徵は全体として平成17年度とほぼ同じと見てょ いことを考慮すると, 試験の成績向上に関しては, 授業で演習問題の解法を重視することが効果的であ り，平成18年度の授業方針でも平成17年度と同様の 教育的効果が見込めると言える.

\section{5. まとめ}

平成16〜18年度の 3 年間に担当した工学基礎物理 の授業について，学生による授業評価を「授業への 真剣さ」に着目して分析した。また，授業評価と成 績との相関を重回帰分析し，年度間で比較した。平 成16年度では理論の解説を重視し，平成17年度では 演習問題の解法に重点を置いたが，平成18年度では 理論の解説と演習問題の解法とのバランスを取った. 授業方法の違いから授業評価並びに成績との相関が どのように変化したかについて，分析した結果をま
とめると次のようになる.

1 ）授業評価に打ける第 $1 ， 2$ 主成分の基本的な性格 は年度（授業のやり方）に依らない.いずれの年度 においても第 1 主成分は教員主導の「授業の良さ (質)」を表し, 第 2 主成分は「学生の基礎学力」に 対応する.

2 ）学生の「授業への真剣さ」は第 2 主成分「基礎学 力」に依存し, その相関が平成 16 年度では正, 平成 17 年度では負であったが, 平成18年度では改善され てほぼ無視できる程度になった。

3 ）授業評価と試験の成績との間の相関は, 平成16年 度の場合と比較して, 平成17, 18年度では非常に弱 い.

4) 平成18年度の授業方法でも, 試験の成績が著し く向上した平成 17 年度と同様の教育的効果が見込め る。

\section{参 考 文 献}

1) 西田昌彦：工学基礎物理における学生による授業 評価の統計的分析と成績との相関分析, 工学教育, $54-4, \mathrm{pp} .48-54,2006$

2 ）西田昌彦：演習問題解法に重点を置いた工学基礎 物理の授業評価と学生の達成感・成績との相関性 の分析, 工学教育, $55-7$, pp. $92-98,2007$

3 ）西田昌彦：問題分割方式による工学基礎教育に おける物理授業改善の試みとその効果, 工学教育, $53-2$, pp. $17-22,2005$

4) 西田昌彦: 工学基礎物理・授業評価の分析, KIT Progress, 14, pp.59-79, 2008

著 者 紹 介

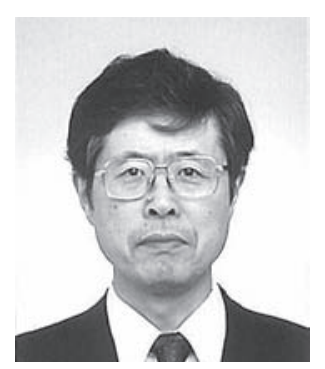

\section{西田 昌彦}

最終学歴：1971年富山大学大学院工学研 究科, 電気工学専攻課程修了

専門分野：半導体ナノ物性

所 属 : 金沢工業大学・数理工教育七 ンター 准教授

学 位: 工学博士

所属学会：日本物理学会 